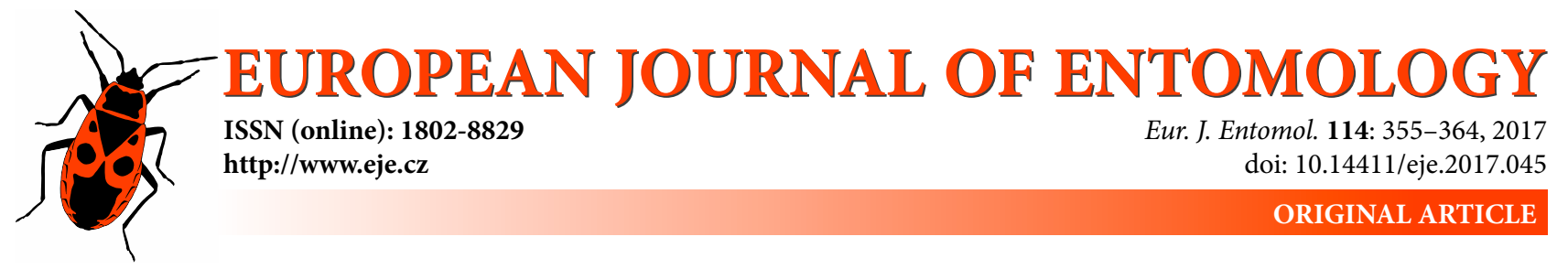

\title{
New species of Cicadocoris (Hemiptera: Coleorrhyncha: Progonocimicidae) from mid-Jurassic deposits in northeastern China
}

\author{
JIA-QIAN JIANG ${ }^{1,2}$ and DI-YING HUANG ${ }^{1 *}$ \\ ${ }^{1}$ State Key Laboratory of Palaeobiology and Stratigraphy, Nanjing Institute of Geology and Palaeontology, Chinese Academy \\ of Sciences, Nanjing 210008, P.R. China; e-mails: jqjiang@nigpas.ac.cn, dyhuang@nigpas.ac.cn \\ ${ }^{2}$ Graduate School, University of Chinese Academy of Sciences, 19A Yuquanlu, Beijing 100049, P.R. China
}

Key words. Hemiptera, Coleorrhyncha, Progonocimicidae, Cicadocoris parvus sp. n., fossil, mid-Jurassic, Daohugou, China

\begin{abstract}
A new progonocimicid bug named Cicadocoris parvus sp. $\mathrm{n}$. is described from the mid-Jurassic Haifanggou Formation at Daohugou, Ningcheng County, Inner Mongolia, northeastern China. It differs from other species by being distinctly smaller, veins dSc, $R_{1}$ and Rs run parallel to one another and are nearly evenly spaced on left tegmen, widest length of apical half/basal half of left tegmen is 1.1 and that of right tegmen is 1.0. Thus, there are at least three species of Cicadocoris (Progonocimicidae) described from Daohugou. All these species are relatively abundant in the Haifanggou Formation and are remarkable representatives of the early Yanliao biota.
\end{abstract}

ZooBank Article LSID: BE181216-421E-4594-9A48-A789D0B3B86F

\section{INTRODUCTION}

Coleorrhyncha is a small suborder of Hemiptera comprised of three families: the extant Peloridiidae Breddin, 1897, the extinct Progonocimicidae Handlirsch, 1906 and Karabasiidae Popov, 1985 (Popov \& Shcherbakov, 1991; Wang et al., 2009). Peloridiidae is a small family with currently a limited distribution in wet moss in temperate and sub-Antarctic rainforests in the Southern Hemisphere (e.g. Chile, Argentina, New Zealand, New Caledonia, southeastern Australia; Burckhardt, 2009; Burckhardt et al., 2011).

The fossil progonocimicids are recorded from the Upper Permian to the Lower Cretaceous and have a remote Gondwana origin. They were widely distributed, occurring in Permian deposits in Australia (Tillyard, 1926), Triassic in Kyrgyzstan (Becker-Migdisova, 1958; Popov \& Shcherbakov, 1991), Australia (Evans, 1956, 1961, 1963; Wootton, 1963) and Argentina (Martins-Neto, 2003), Jurassic in Kyrgyzstan (Popov, 1982, 1985), United Kingdom (Popov et al., 1994), China (Hong, 1983; Dong et al., 2012, 2013, 2014), Russia (Popov, 1985, 1988), Germany (Handlirsch, 1939; Popov \& Wootton, 1977), Luxembourg (Szwedo, 2011), and Cretaceous in Lebanon (Szwedo et al., 2011), United Kingdom (Handlirsch, 1906; Klimaszewski \& Popov, 1993), Argentina (Martins-Neto, 2003), Mongolia
(Popov, 1986) and Russia (Popov, 1988). Based on our recent unpublished data it also occurs in mid-Cretaceous Burmese amber. Karabasiids are reported from the Lower Jurassic to the Lower Cretaceous, including Jurassic in Mongolia (Popov, 1989), Russia (Popov \& Shcherbakov, 1991; Becker-Migdisova, 1958; Popov, 1985), Kyrgyzstan (Martynov, 1926) and China (Lin, 1986; Wang et al., 2011), and Cretaceous in Russia (Popov \& Shcherbakov, 1991).

The genera in Progonocimicidae are complicated. Olgamartynovia Becker-Migdisova, 1958, Mesoscytina Hong, 1983, Mesocimex Hong, 1983, and Asianisca Popov, 1985 were synonymized with Cicadocoris Becker-Migdisova, 1958. Popov \& Shcherbakov (1991) transferred 10 species of Olgamartynovia to Mesoscytina and 10 to Cicadocoris, two species of Asianisca to Mesoscytina and one to Cicadocoris. They also proposed that Mesocimex is a synonym of Mesoscytina. Wang et al. (2009) found that the generic name Mesoscytina had already been used and the valid generic name should be Mesocimex. However, Mesocimex was very similar to Cicadocoris and a species named Cicadocoris assimilis Dong, Yao \& Ren, 2013 had characters typical of both Mesocimex and Cicadocoris. The two genera were discussed and considered synonymous (Dong et al., 2012, 2013). Thus, Cicadocoris is currently the larg-

\footnotetext{
* Corresponding author; e-mail: dyhuang@nigpas.ac.cn
} 


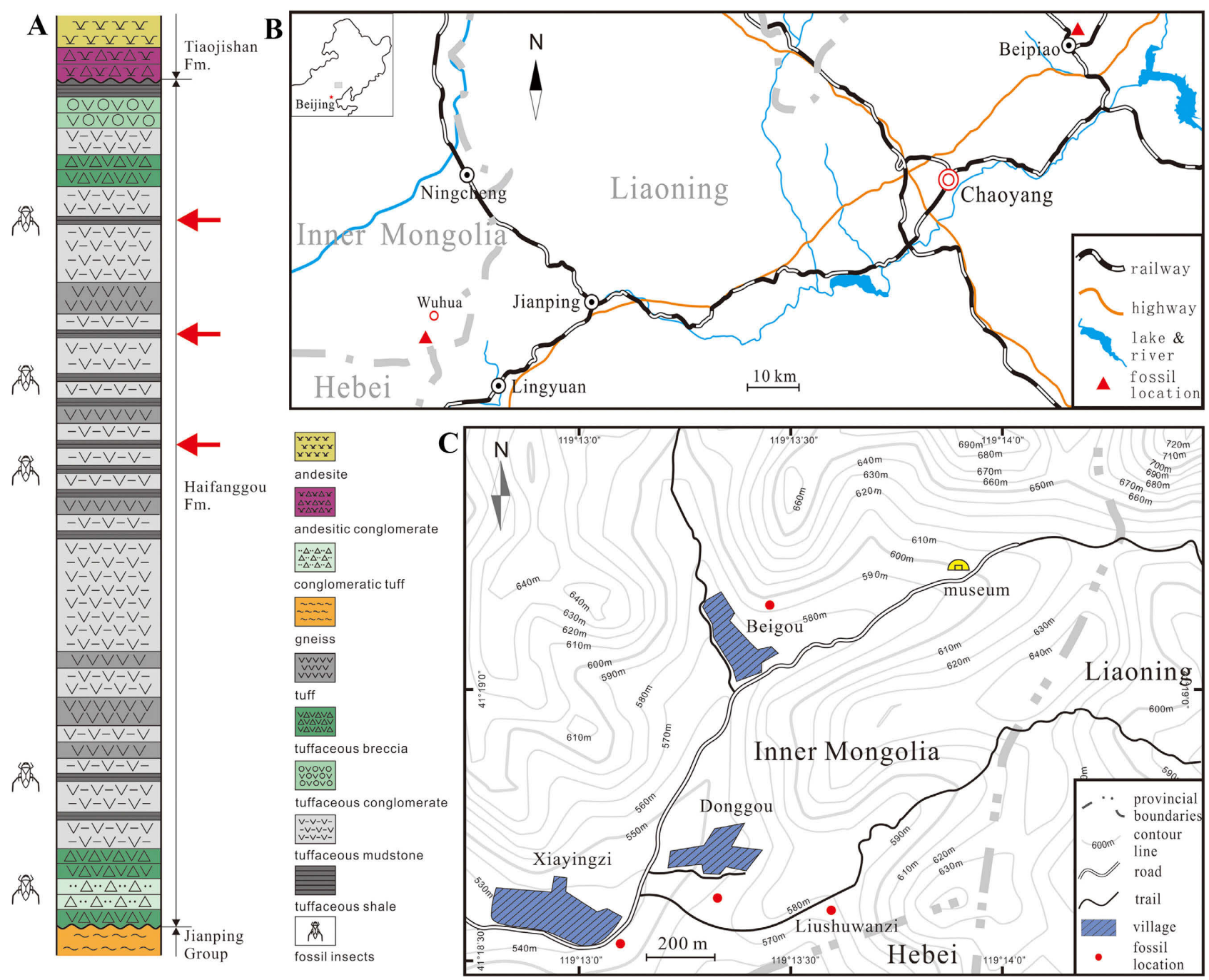

Fig. 1. A - stratigraphic column for the Haifanggou Fm. near Daohugou, Ningcheng County, Inner Mongolia, NE China (red arrows indicate the fossil layers that yielded new species); B - map showing the location of Daohugou and Yujiagou (red triangles); C - map showing locations near Daohugou (red spots).

est of the 23 genera currently considered valid in the Progonocimicidae, and is reported from the Late Triassic to Middle Jurassic (Becker-Migdisova, 1958; Popov, 1982, 1985; Hong, 1983; Dong et al., 2013).

The fossil progonocimicids are easily collected from the mid-Jurassic Haifanggou Formation (Daohugou beds) in Ningcheng County, Inner Mongolia (Wang et al., 2009; Dong et al., 2012, 2013, 2014) and localities near Haifeng, Beipiao, Liaoning Province (Hong, 1983; Jiang et al., 2016) (Fig. 1B). The Daohugou beds mainly occur at Wuhua near the border between the Inner Mongolia, Hebei and Liaoning provinces. The lacustrine deposits have yielded hundreds of progonocimicid specimens and other abundant fossil insects of more than 20 orders (Huang, 2015). The age of this fauna seems very close to the middle and late Jurassic boundary (163.5 Ma) (Huang, 2016).

\section{MATERIAL AND METHODS}

The material studied includes a total of 40 individuals (21 males, 12 females and 7 undetermined); most of them are com- plete or nearly complete, and 16 of them are with counterparts. Most specimens (39) were collected from several localities near Daohugou and Wuhua, Ningcheng County, Inner Mongolia, northeastern China (Fig. 1C). They are preserved in whitish or greyish fine laminated tuffaceous shale (Xiayingzi, Donggou and Beigou) or strongly weathered yellowish muddy shale (Liushuwanzi). Only one specimen was collected from the yellow-brownish shale at Yujiagou near Haifeng, Sanbao and Beipiao, Liaoning Province. All these fossils are from the Haifanggou Formation with a geological age close to the middle-late Jurassic boundary.

Some specimens were carefully prepared using a sharp knife. All fossils were studied using a Leica MZ16A dissecting microscope. Maps and line drawings were drawn with CorelDRAW X6 graphic software. Photographs were taken with a digital camera attached to a Leica MZ16A microscope. Specimens in a few photographs were moistened with $70 \%$ ethanol to show the fine details (e.g. teeth-bearing structure of hind tibia and tarsi). All type material is deposited in the Nanjing Institute of Geology and Palaeontology. We follow the wing venation nomenclature as amended by Popov \& Shcherbakov (1991). 

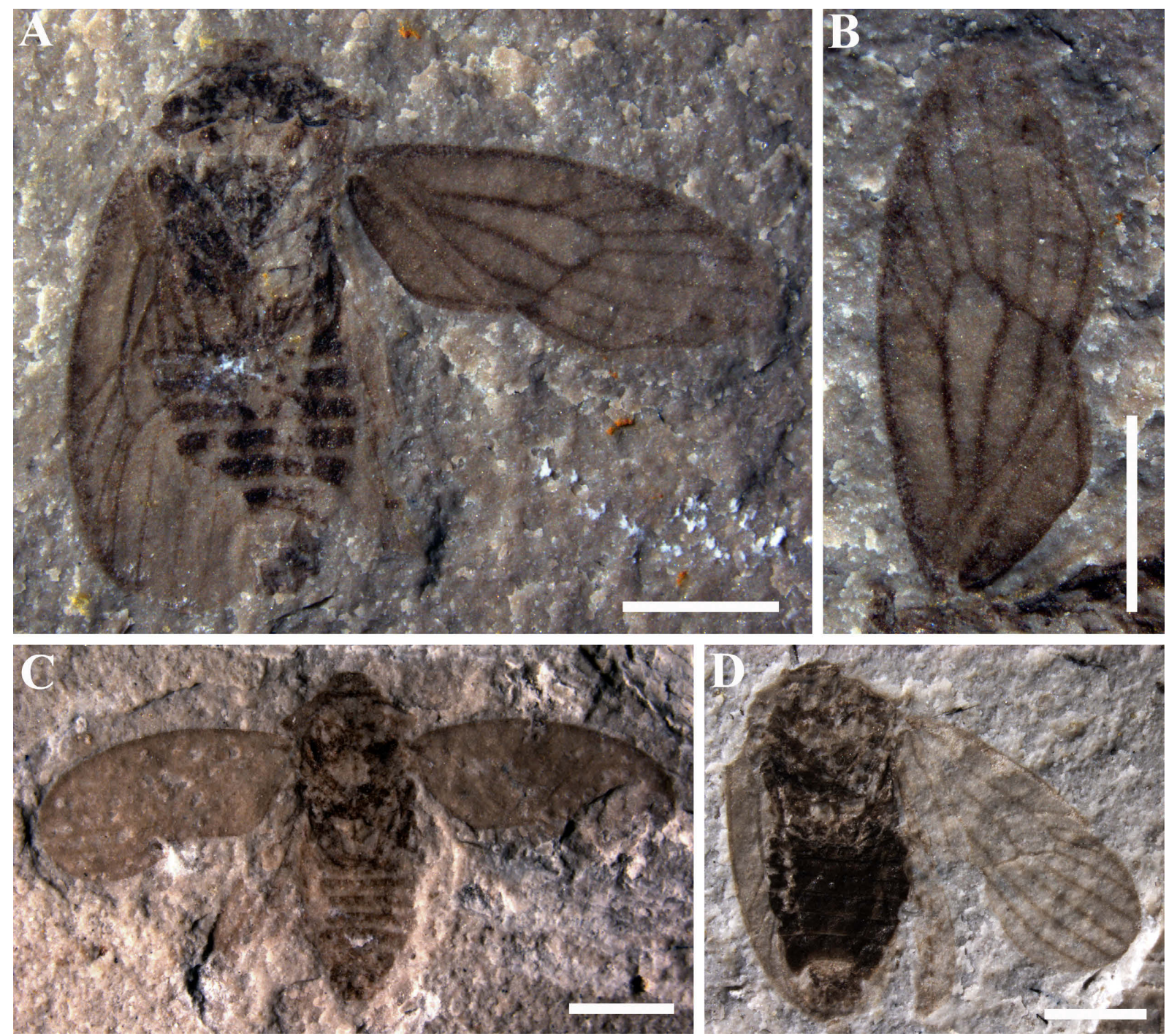

Fig. 2. Males of Cicadocoris parvus sp. n. with tegmina extended. A - holotype, (NIGP165304), a complete male, showing general habitus; B - left tegmen, showing venation; C - complete male (NIGP165305), showing general habitus and venation; D - complete male (NIGP165306), showing general habitus and venation. Scale bars: $1 \mathrm{~mm}$.

\section{SYSTEMATIC PALEONTOLOGY}

\section{Order Hemiptera Linnaeus, 1758}

Suborder Coleorrhyncha Myers et China, 1929

Family Progonocimicidae Handlirsch, 1906

Subfamily Cicadocorinae Becker-Migdisova, 1958

Genus Cicadocoris Becker-Migdisova, 1958

Type species. Cicadocoris kuliki Becker-Migdisova, 1958 (original designation).

Olgamartynovia Becker-Migdisova, 1958: 62. Type species: $O$. turanica Becker-Migdisova, 1958 (original designation). Synonymized by Popov \& Shcherbakov, 1991.

Liadoscytina Popov, 1982: 81. Nomen nudum.

Mesocimex Hong, 1983: 65. Type species: M. sinensis Hong, 1983 (original designation). Synonymized by Dong et al., 2013.

Mesoscytina Hong, 1983: 66 (nec Tillyard, 1919; Scytinopteridae). Type species: M. brunnea Hong, 1983 (original designation). Synonymized by Popov \& Shcherbakov, 1991.

Asianisca Popov, 1985: 33 (A. ambigua; A. incompleta; A. modesta). Type species: A. modesta Popov, 1985 (original designation). Synonymized by Popov \& Shcherbakov, 1991.
Genus diagnosis. Head small; eyes oval; antennae clavate; rostrum thin, extends to basal hind coxae; pronotum trapezoidal; hind tibia with two large movable conical spurs; hind tarsi three-segmented, apex of hind tibia and tarsomeres bear tiny teeth; costal margin arcuate; precostal carina narrow nearly horizontal; abdomen roughly oval, longer than wide with sternite 4 broadest, sternite 9 short, ovipositor extends slightly beyond sternite 9 .

\section{Cicadocoris parvus sp. $\mathrm{n}$.}

(Figs 2-7)

ZooBank taxon LSID:

937376DA-5BD4-4CFF-9379-1B0B3A0DEAEB

Etymology. Derived from the Latin parvus meaning "small", or "little" to indicate the small size of this new species.

Type material. Holotype NIGP165304, male, a well-preserved complete specimen with one extended tegmen, without counterpart. It was collected from the Xiayingzi locality. Paratypes. Males: NIGP165305-NIGP165313, NIGP166188-NIGP166198; females: NIGP165314-NIGP165319, NIGP165325-NIGP165326, 

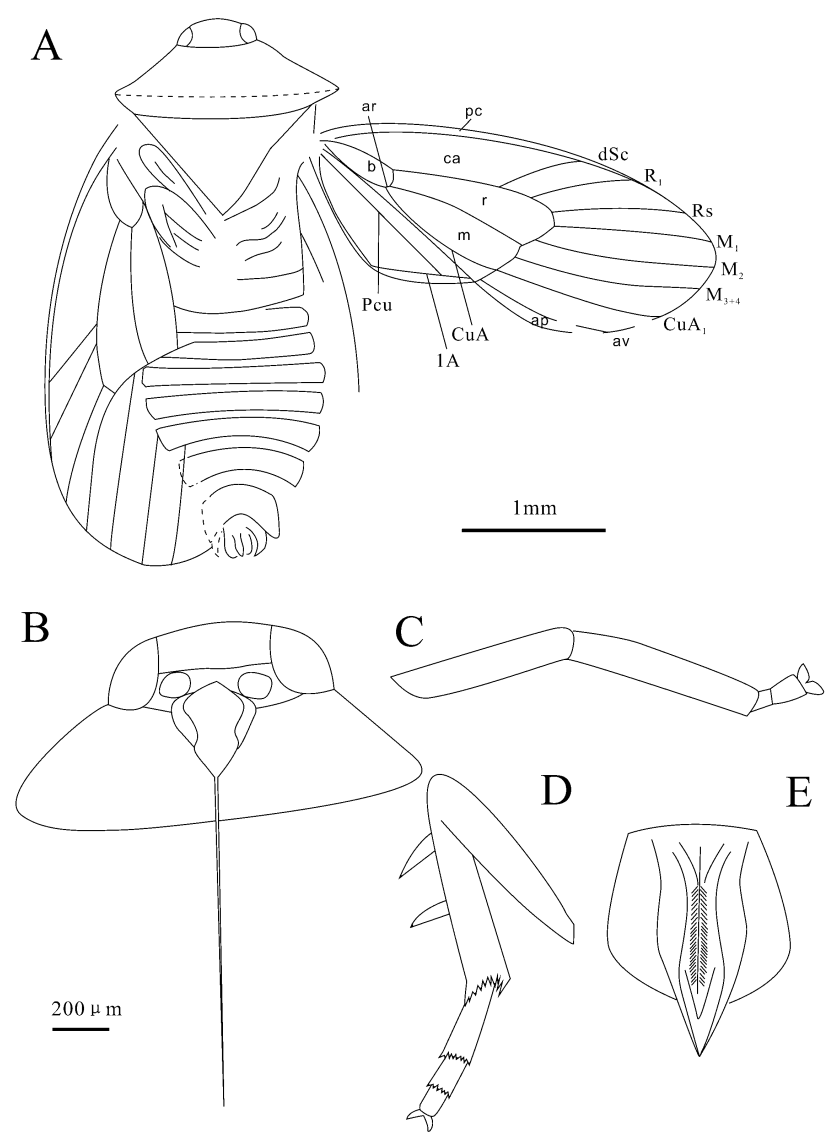

Fig. 3. Line drawings of Cicadocoris parvus sp. n. A - holotype (NIGP165304); B-head (NIGP165313); C-fore leg (NIGP166190); D - hind leg (NIGP165315); E - ovipositor (NIGP165319). Scale bars: $1 \mathrm{~mm}$ in A, $200 \mu \mathrm{m}$ in B-E. ap - appendix, ar - arculus, av - ambient vein, b - basal cell, ca - costal area, dSc - apex of Sc, $\mathrm{m}$ - medial cell, $\mathrm{pc}$ - precostal carina, Cua - cubitus anterior Pcu - postcubitus.

NIGP166189-NIGP166202; unknown sexes: NIGP166203NIGP166209.

Type locality, formation and age. Daohugou, Ningcheng County, Inner Mongolia, China; Haifanggou Formation; mid-Jurassic.

Diagnosis. Small size, differs from other species by its distinctly smaller body size $(2.8-3.9 \mathrm{~mm})$; veins dSc, R1 and Rs sub-parallel and nearly evenly spaced on left tegmen; left tegmen, widest length of apical half/basal half is 1.1 and that of right tegmen is $1.0 ; 21$ visible ridges along median section of female ovipositor; wing length/body length is 0.83 in male, 0.92 in female.

Description. Body 2.8-3.9 mm long, tegmen 2.5-3.8 $\mathrm{mm}$ long. Small insect, oval to round in outline. Head small, without areolae. Compound eyes oval. Antennae four segmented, antennal socket closer to postclypeus than eyes (Figs 3B, 5B, H). Anteclypeus subtriangular, laterally indented to postclypeus (Fig. 5B). Postclypeus rounded and slightly convex. Lora semicircular and completely separated. Rostrum thin, directed caudad, reaching base of hind coxae (Figs 5B, 6D).

Pronotum trapeziform, 1.8-2.2 times as wide as head, with weakly concave fore edge, lateral edges curled, slightly arcuate, posterior angles blunted, 3.8 times as wide as long. Scutellum medium-sized, triangular, 1.5-1.8 times as wide as long. Legs slight increasing in size from fore to hind legs, femur as long as tibia. Fore and middle tarsi two-segmented, hind tarsi three-segmented (Figs 3C, D, $4 \mathrm{~F}, 5 \mathrm{E}, 6 \mathrm{G}, 7 \mathrm{G})$. Hind coxae enlarged and transverse. Hind tibia bear two large lateral movable spurs that are 0.3 times shorter than length of tibia, one near the base and the other near the middle (Figs 3D, 4E, 5E, 6F, G, 7G), apex of hind tibia and tarsomeres bear tiny teeth (Figs 4F, 6G). Hind tibia armed with at least 10 visible apical tiny teeth (Figs 3D, 4E, J, 5C, 6I, J). Basal tarsomere distinctly longer than second and third tarsomeres together, basal tarsomere 2.0-2.2 times length of second tarsomere, apex of basal tarsomere and second tarsomere armed with at least 8 tiny teeth (Figs 3D, 5C, 6I, J, 7J).

Tegmen (Figs 2, 3) length-width ratio 2.5, with widest part 3/4 along the length of wing. Anterior margin weakly arcuate, with apex at apex of vein $\mathrm{M}_{3+4}$. Precostal carina narrow and horizontal. Costal area narrow, not widening towards dSc, dSc straight. Stem of R slightly convex at point of $\mathrm{dSc}$ origin, dividing into $\mathrm{R}_{1}$ and $\mathrm{Rs}$ halfway between the fork in $\mathrm{M}$ and costal margin, slightly beyond basal forking of $\mathrm{M}$. Arculus short and sub transverse. $\mathrm{M}_{1+2}$ dividing before $\mathrm{r}-\mathrm{m}, \mathrm{M}_{3+4}$ longer than stem $\mathrm{M}$. Stem $\mathrm{CuA}$ beyond arculus curved. $\mathrm{CuA}_{2}$ transverse. Length of radial cell 0.36 times as long as tegmen, length of medial cell 0.34 times as long as tegmen. Right tegmen cu-a, m-cu, base of $\mathrm{M}_{3+4}$, $\mathrm{M}_{1+2}$ and $\mathrm{M}_{1}$ form distinct and continuous transverse arc, distance from $\mathrm{dSc}$ origin to that of $\mathrm{R}_{1} 1.1-1.5$ times longer than that from the origin of $R_{1}$ to that of Rs, veins $d S c, R_{1}$ and Rs sub-parallel, $M_{1}$ arcuate and closer to Rs than $M_{2}$, width of apical half 1.0 times that of basal half. Left tegmen without arc, origin of $R_{1}$ in the middle of that of $d S c$ and Rs, veins $\mathrm{dSc}, \mathrm{R}_{1}$ and Rs parallel and evenly spaced, $M_{1}$ on left tegmen straight, equals Rs and $M_{2}$, width of apical half 1.1 times that of basal half. Hindwing rounded apically, with apex at apex of vein $\mathrm{M}_{1+2}$. Vein Rs connected to $\mathrm{M}_{1+2}$ by a sub transverse cross vein $\mathrm{r}-\mathrm{m}$ a little distal of the origin of $M_{1+2}$. Stem $M$ forks into $M_{1+2}$ and $M_{3+4}$ little beyond middle of wing. Vein $\mathrm{M}_{3+4}$ fused with vein $\mathrm{CuA}$. Stem of $\mathrm{CuA}$ bifurcates into veins $\mathrm{CuA}_{1}$ and $\mathrm{CuA}_{2}$ at same level as the stem of $\mathrm{M}$ branches.

Abdomen slightly longer than wide. Lateral tergites 4-6 4.0 times narrower than sternites. Sternite IV broadest, sternite VIII curved, sternite IX small and blunt apically. Ovipositor 0.8 times as wide as long, extends slightly beyond apex of sternite 9 , shorter than apex of tegmina, consisting of three pairs of valvulae and narrows anteriorly, with 24 visible ridges along its median section(Figs 3E, 6C, D, 7H, I). Male pygophore barrel-shaped, 0.92 times as wide as long (Figs 4B, G, H, 5A, E, H).

Measurements (in $\mathrm{mm}$ ). The average value of the body length (head to apex of genitalia) of Cicadocoris parvus is $3.50 \mathrm{~mm}$, wing length is $2.99 \mathrm{~mm}$; the median length of the body is 3.51 $\mathrm{mm}$, wing length is $3.00 \mathrm{~mm}$ (Table 1). Holotype, NIGP165304 (male): body length 3.68 , body width 1.29 ; head length 0.20 , width 0.53 ; pronotum length 0.50 , width 1.57 ; left tegmen: length 3.02, width 1.18; arculus 0.02 ; dSc 0.69 ; R1 0.78 , Rs $0.93 ; \mathrm{M}_{1}$ 

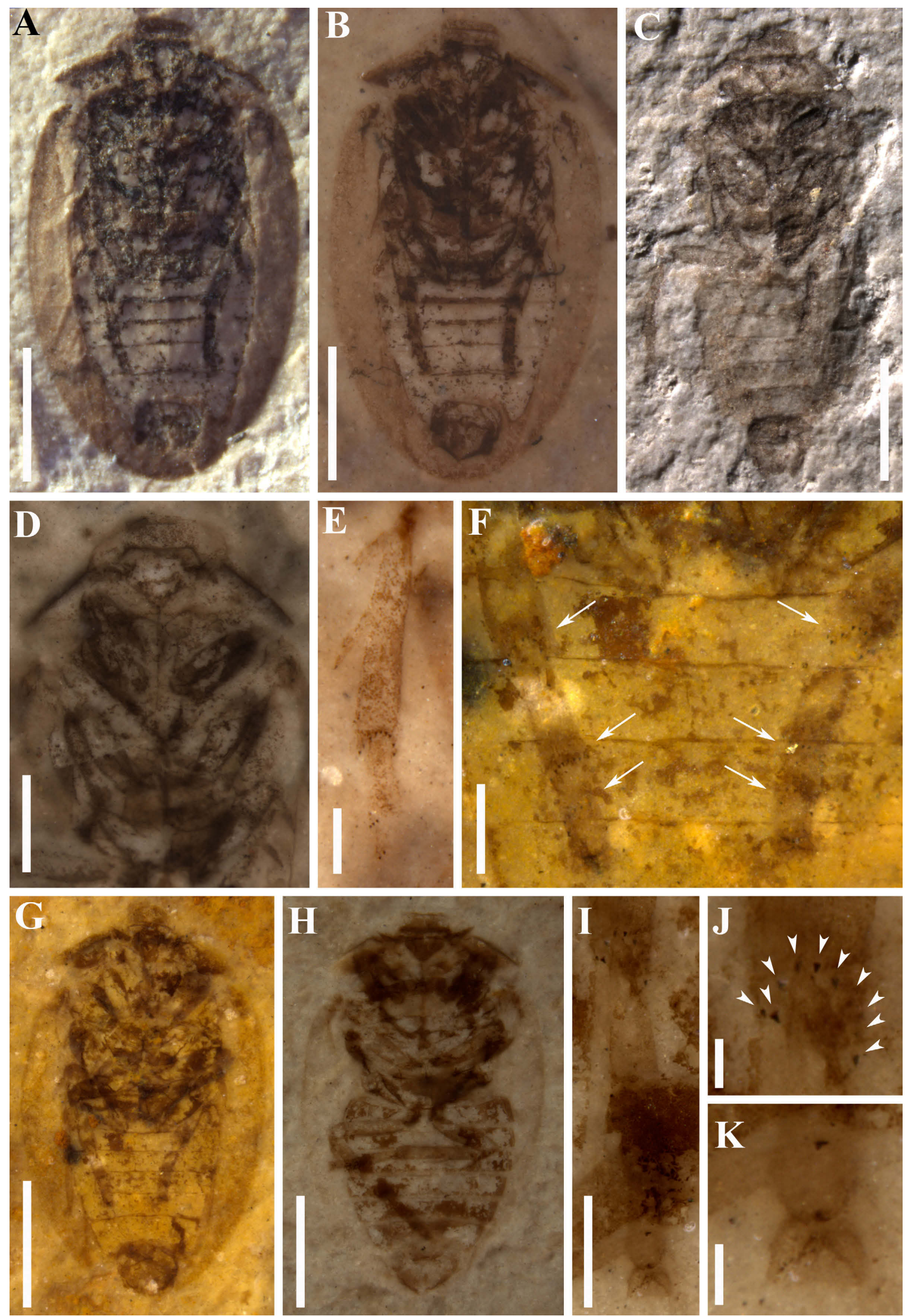

Fig. 4. Cicadocoris parvus sp. n., males, from the Haifanggou Formation at Daohuguo. A - NIGP165307, general habitus; B NIGP165307(A), general habitus and body structures; C - NIGP165308, general habitus with tegmina under rock; D - enlargement of C, showing the details of rostrum and legs; $E$ - enlargement of $C$, showing details of hind leg; $F$ - enlargement of $G$, showing the tiny teeth on the apices of the tibia and tarsi (indicated by white arrows); G - NIGP165309, general habitus; H - NIGP165310, general habitus; I enlargement of $\mathrm{H}$, showing details of the tiny teeth on the apices of tibia and tarsi; $\mathrm{J}$ - enlargement of $\mathrm{H}$, showing the apical teeth on hind tibia (white arrows); $\mathrm{K}$ - enlargement of $\mathrm{H}$, details of claws. B, D, E, F, G, H, I, J, K moistened with $70 \%$ ethanol. Scale bars represent 1 $\mathrm{mm}$ in $\mathrm{A}, \mathrm{B}, \mathrm{C}, \mathrm{G}, \mathrm{H} ; 0.5 \mathrm{~mm}$ in $\mathrm{D} ; 0.2 \mathrm{~mm}$ in $\mathrm{E}, \mathrm{F}, \mathrm{I} ; 50 \mu \mathrm{m}$ in $\mathrm{J}, \mathrm{K}$. 

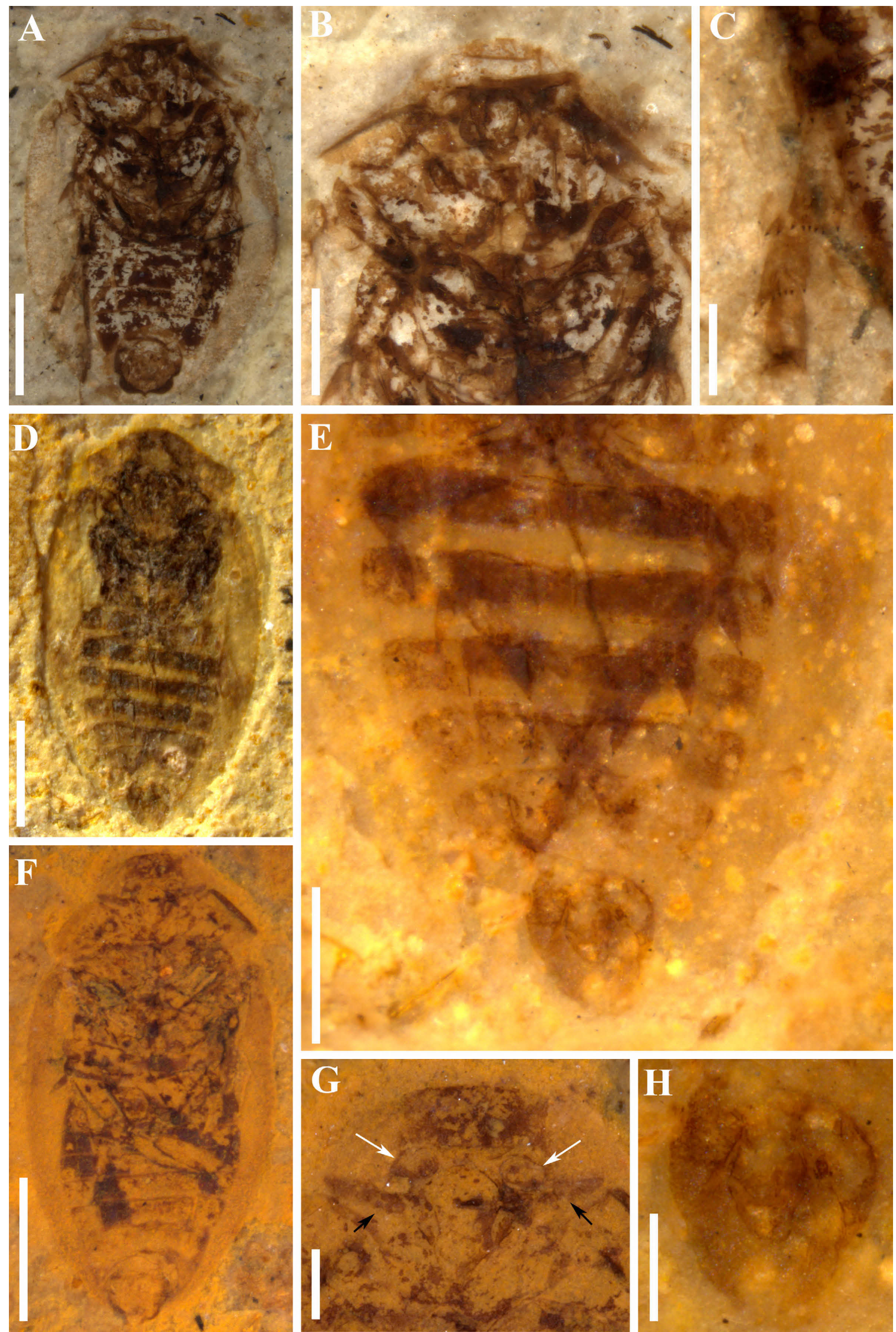

Fig. 5. Photographs of males of Cicadocoris parvus sp. n., from the Haifanggou Formation at Daohugou. A - NIGP165311, general habitus; $B$ - enlargement of $A$, showing details of mouthparts and antennal socket; $C$ - enlargement of $A$, showing the tiny teeth on the apices of tibia and tarsi; D - NIGP165312, general habitus; E - enlargement of D, showing the details of hind legs and pygophore; F NIGP165313, general habitus; G - enlargement of F, showing the details of antennae (indicated by black arrows) and antennal socket (indicated by white arrows); $\mathrm{H}$ - enlargement of $\mathrm{d}$, showing the details of pygophore. A, B, C, E, F, G, H moistened with $70 \%$ ethanol. Scale bars represent $1 \mathrm{~mm}$ in A, D, F; $0.5 \mathrm{~mm}$ in B, E; $0.2 \mathrm{~mm}$ in G, H, C. 

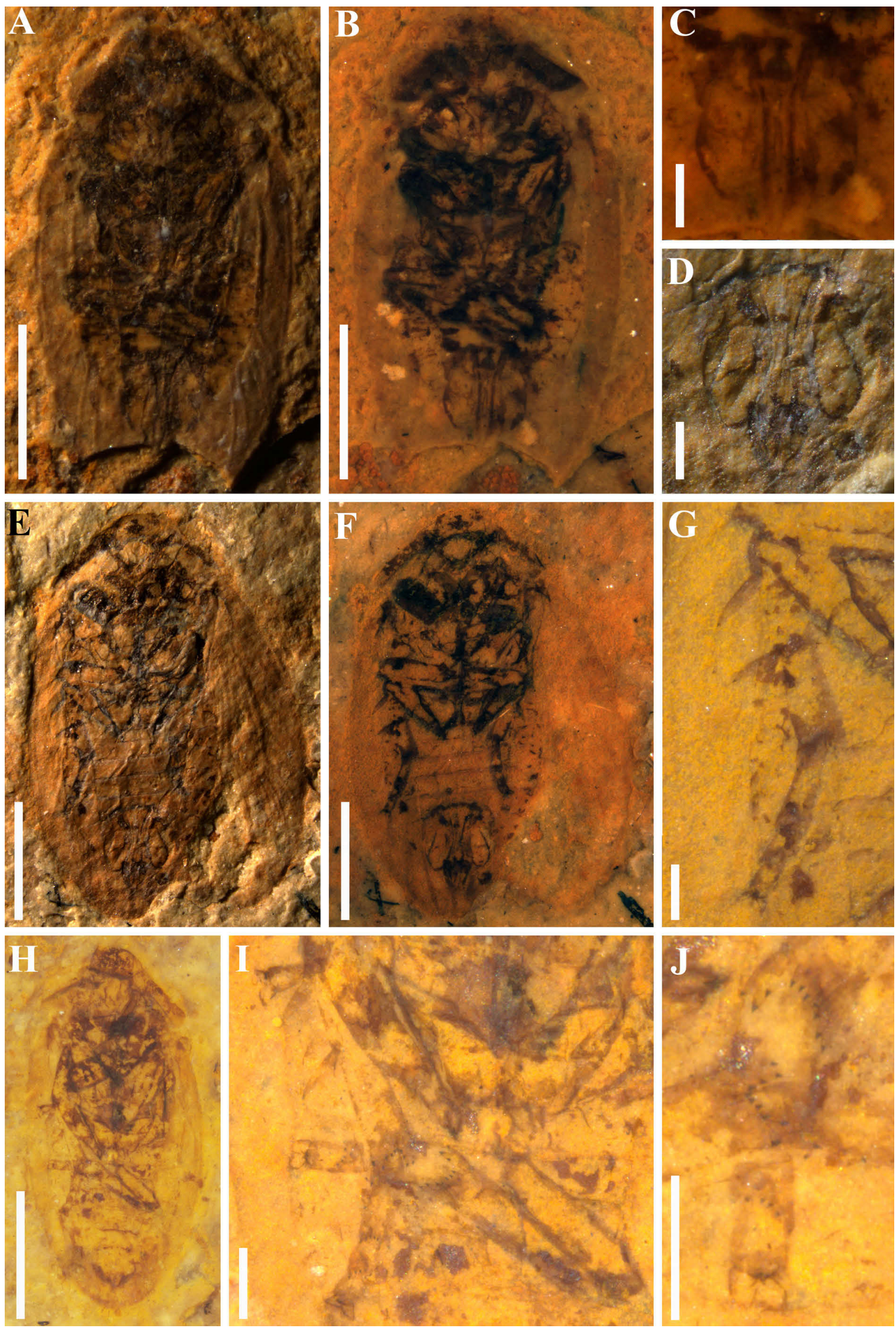

Fig. 6. Photographs of females of Cicadocoris parvus sp. n., from the Haifanggou Formation at Daohugou. A - NIGP165314, general habitus; B - NIGP165314(A), general habitus; C - enlargement of A, showing the details of ovipositor; D - enlargement of E, showing the details of ovipositor; E - NIGP165315, general habitus; F - NIGP165315 (E), general habitus and body structures; G - enlargement of A, showing the details of hind leg; $\mathrm{H}$ - NIGP165316, general habitus; I - enlargement of $\mathrm{H}$, showing the details of hind legs; J - enlargement of $\mathrm{H}$, showing the tiny teeth on the apices of the tibia and tarsi. B, C, F, G, H, I, J moistened with $70 \%$ ethanol. Scale bars represent 1 $\mathrm{mm}$ in $\mathrm{A}, \mathrm{B}, \mathrm{E}, \mathrm{F}, \mathrm{H} ; 0.2 \mathrm{~mm}$ in $\mathrm{C}, \mathrm{D}, \mathrm{G}, \mathrm{I}, \mathrm{J}$. 

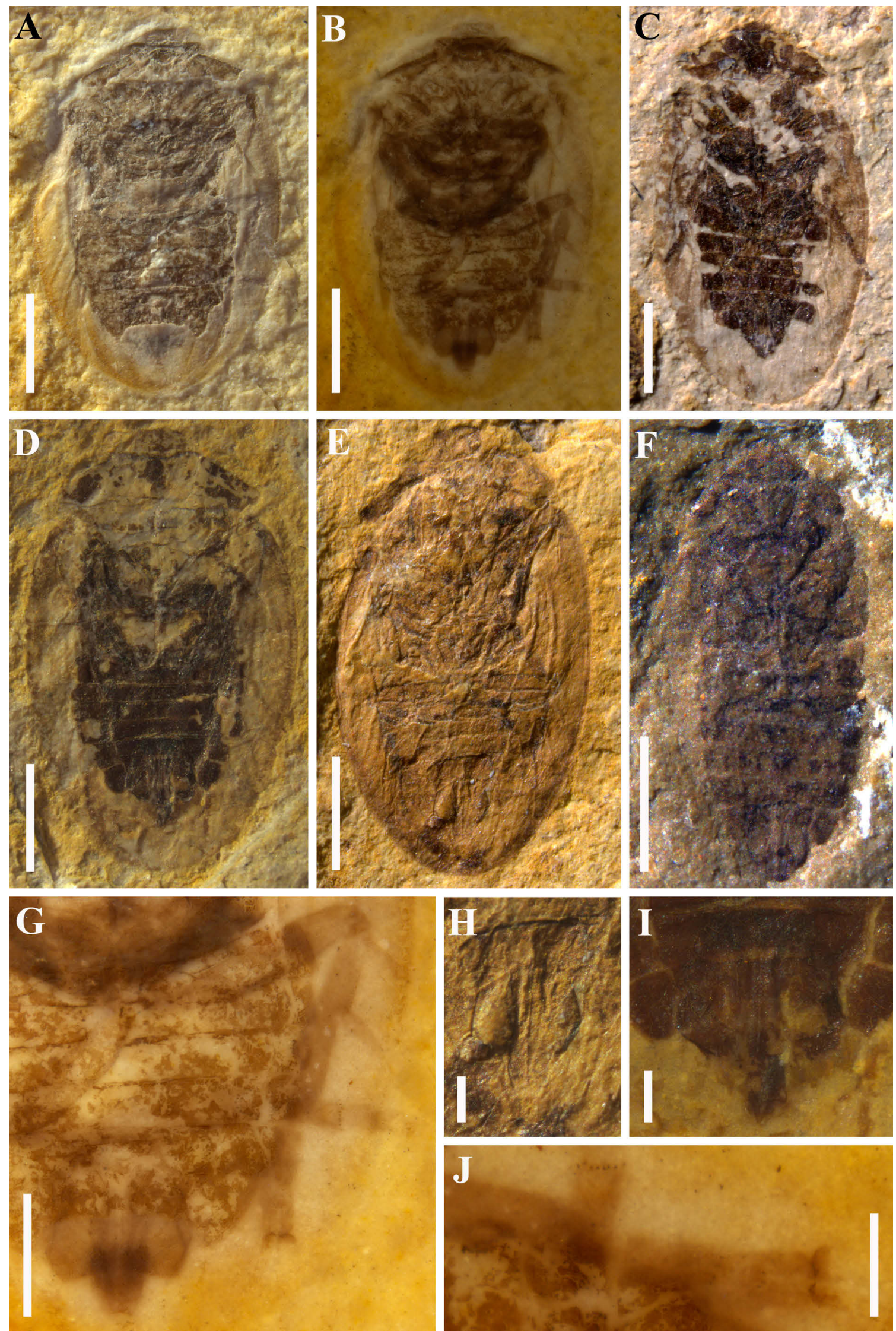

Fig. 7. Photographs of females of Cicadocoris parvus sp. n., from the Haifanggou Formation at Daohugou (A-E, G-J) and Yujiagou (F). A - NIGP165317, general habitus; B - NIGP165317(A), showing general habitus; C - NIGP165318, showing general habitus; D - NIGP165319, the details of ovipositor; E - NIGP165325, general habitus; F - NIGP165326, general habitus; G - enlargement of B, showing details of hind legs and ovipositor; $\mathrm{H}$ - enlargement of $\mathrm{E}$, showing details of ovipositor; I - enlargement of $\mathrm{D}$, showing details of ovipositor; J - enlargement of B, showing the tiny teeth on apices of tarsomere and claws. B, G, I, J moistened with $70 \%$ ethanol. Scale bars represent $1 \mathrm{~mm}$ in $\mathrm{A}, \mathrm{B}, \mathrm{C}, \mathrm{D}, \mathrm{E}, \mathrm{F} ; 0.5 \mathrm{~mm}$ in $\mathrm{G} ; 0.2 \mathrm{~mm}$ in $\mathrm{H}, \mathrm{I}, \mathrm{J}$. 
Table 1. Measurements of Cicadocoris parvus.

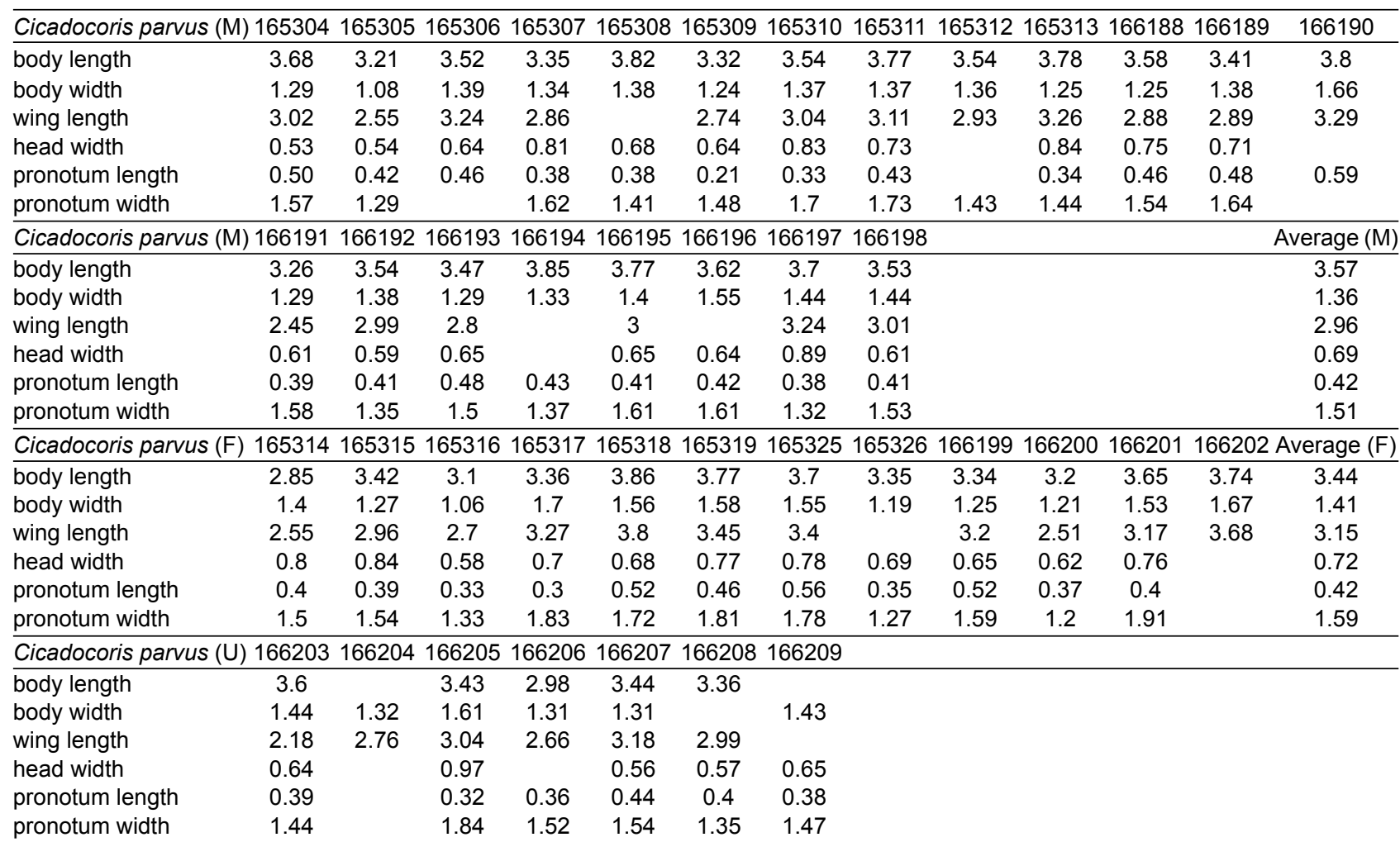

Note: $\mathrm{M}$ - male; $\mathrm{F}$ - female; $\mathrm{U}$ - unknown sex; all the values are in $\mathrm{mm}$.

$1.11, \mathrm{M}_{2} 1.32, \mathrm{M}_{1+2} 0.11, \mathrm{M}_{3+4} 1.30 ; \mathrm{CuA}_{1} 1.16, \mathrm{CuA}_{2} 0.14,1 \mathrm{~A}$ 0.68 , Pcu 1.22. Paratype, NIGP165315 (female): body length 3.42 , body width 1.27 ; head length 0.32 , width 0.84 ; pronotum length 0.39 , width 1.54 ; length of hind coxa 0.46 , hind femur 0.65 , hind tibia 0.60 , hind tarsomeres I-III: $0.28,0.14,0.12$.

\section{DISCUSSION}

This new species is assigned to Cicadocoris based on the following constitutive characters: small head; clavate antennae; rostrum thin, extends to base of hind coxae; trapezoidal pronotum; hind tibia with two large movable conical spurs; hind tarsi three-segmented; tegmen at claval apex wider than $1 / 3$ of full length; costal margin arcuate; precostal carina narrow; $\mathrm{M}_{3+4}$ longer than stem of $\mathrm{M}$.

Cicadocoris parvus sp. n. shares several critical characters with C. sinensis (Hong 1983), such as costal area not widening toward $\mathrm{dSc}$, stem of $\mathrm{M}$ shorter than $\mathrm{M}_{3+4}$, and the ratio of the widest length of apical half/basal half of the left tegmen larger than the right tegmen. In addition, the body length of this new species ranges from $2.8-3.9 \mathrm{~mm}$ and that of $C$. sinensis is $3.7-5.4 \mathrm{~mm}$, with an overlapping region. Thus the body sizes of these two species are not strictly different. However, the new species differs from $C$. sinensis in the following characters: (1) veins $\mathrm{dSc}, \mathrm{R}_{1}$ and Rs sub-parallel; (2) normal distance from dSc origin to $\mathrm{R}_{1}$ origin 1.1-1.5 times longer than $\mathrm{R}_{1}$ origin to $\mathrm{Rs}$ origin on right tegmen (1.5-2.5 times in $C$. sinensis); (3) the ratio of the widest length of apical half is 1.1 times that of the basal half on left tegmen and 1.0 times on right tegmen (1.2 times and 1.1 times for $C$. sinensis, respectively); ovi- positor has 24 visible ridges along its median section, 8-9 ridges $/ 100 \mu \mathrm{m}$ (13 visible ridges, $3-4$ ridges $/ 100 \mu \mathrm{m})$.

C. parvus closely resembles C. brunneus (Hong, 1983) in its venation. The body length of $C$. brunneus is 5.2-7.0 $\mathrm{mm}$, circa twice as large as the new species. C. parvus sp. n., C. sinensis and C. brunneus always co-occur in the major fossil layers in the Daohugou beds, which excludes the possibility that the new species and C. brunneus are the same species.

C. parvus differs from the type species Cicadocoris $\mathrm{ku}$ liki Becker-Migdisova, 1958 in its body length $2.8-3.9 \mathrm{~mm}$ (vs. 2.8-5.8 $\mathrm{mm}$ in C. kuliki); $\mathrm{M}_{2}$ does not have a common stalk with $M_{1}$ (vs. $M_{2}$ has a common stalk with $M_{1}$ ); costal area does not widen towards dSc (vs. costal area much wider toward $\mathrm{dSc}$ ).

Five species of Cicadocoris are so far described from the Daohugou beds. Two species namely $C$. varians and $C$. assimilis erected based on a single specimen (Dong et al., 2012, 2013). Among them, at least $C$. varians is probably a junior synonym of $C$. sinensis because of taphonomic deformation. Three of them (C. sinensis $C$. brunneus and $C$. parvus) are abundant in the Daohugou beds at Ningcheng, Inner Mogolia and localities near Haifeng (type section of the Haifanggou Fm.), Beipiao, Liaoning Province (Jiang et al., 2016). This is convincing evidence of the stratigraphic similarity of the Daohugou beds and the type locality of the Haifanggou Formation. Cicadocoris are distinct representatives of an early assemblage of the famous Yanliao biota that became extinct, probably due to a great tectonic movement and volcanic explosion (Huang, 2015; Jiang et al., 2016). 
ACKNOWLEDGEMENTS. This work was funded by the Ministry of Science and Technology (2016YFC0600406), the Strategic Priority Research Program of the Chinese Academy of Sciences (XDB18000000), and the National Natural Science Foundation of China (41688103 and 91514302). This study is a contribution to UNESCO-IUGS IGCP Project 632.

\section{REFERENCES}

Becker-Migdisova E.E. 1958: New fossil Homoptera. Pt. 1. Mater. Osnov. Paleontol. 2: 57-67 [in Russian].

Breddin G. 1897: Hemipteren. In Michaelsen W. (ed.): Ergebnisse der Hamburger Magalhaensischen Sammelreise 1892/93. II. Band: Arthropoden. Herausgegeben vom Naturhistorischen Museum zu Hamburg. L. Friederischen \& Co., Hamburg, 37 pp., 1 pl.

BuRCKHARDT D. 2009: Taxonomy and phylogeny of the Gondwanan moss bugs or Peloridiidae (Hemiptera, Coleorrhyncha). Dt. Entomol. Z. 56: 173-235.

Burckhardt D., Bochud E., Damgaard J., GibBs G.W., Hartung V., Larivière M.C., Wyniger D. \& ZÜrcher I. 2011: A review of the moss bug genus Xenophyes (Hemiptera: Coleorrhyncha: Peloridiidae) from New Zealand: systematics and biogeography. - Zootaxa 2923: 1-26.

Dong Q.P., Yao Y.Z. \& Ren D. 2012: A new species of Progonocimicidae (Hemiptera, Coleorrhyncha) from Northeastern China. - Zootaxa 3495: 73-78.

Dong Q.P., YAo Y.Z. \& Ren D. 2013: A new species of Progonocimicidae (Hemiptera, Coleorrhyncha) from the Middle Jurassic of China. - Alcheringa 37: 31-37.

Dong Q.P., Yao Y.Z. \& Ren D. 2014: New fossil Progonocimicidae (Hemiptera: Coleorrhyncha: Progonocimicoidea) from the Upper Mesozoic of northeastern China, with a phylogeny of Coleorrhyncha. - Syst. Entomol. 39: 773-782.

Evans J.W. 1956: Palaeozoic and Mesozoic Hemiptera (Insecta). — Aust. J. Zool. 4: 164-258.

Evans J.W. 1961: Some Upper Triassic Hemiptera from Queensland. - Mem. Queensl. Mus. 14: 13-23.

Evans J.W. 1963: The phylogeny of Homoptera. - Annu. Rev. Entomol. 8: 77-94.

Handlirsch A. 1906-1908: Die Fossilen Insekten und die Phylogenie der rezenten Formen. Ein Handbuch für Paläontologen und Zoologen. Engelmann, Leipzig, $1430 \mathrm{pp}$.

HandLIRSCH A. 1939: Neue Untersuchungen über die Fossilen Insekten mit Ergänzungen und Nachträgen sowie Ausblicken auf phylogenetische, palaeogeographische und allgemein biologische Probleme. Teil 2. - Ann. Nat. Hist. Mus. Wien 49: 1-240.

Hong Y.C. 1983: Middle Jurassic fossil insects in North China. Geological Publishing House, Beijing, 223 pp. [in Chinese].

Huang D.Y. 2015: Yanliao Biota and Yanshan movement. - Acta Palaeontol. Sin. 54: 501-546 [in Chinese, English abstr.].

Huang D.Y. 2016: The Daohugou Biota. Shanghai Scientific \& Technical Publishers, Shanghai, 336 pp. [in Chinese].

JiANG J.Q., CAI C.Y. \& Huang D.Y. 2016: Progonocimicids (Hemiptera, Coleorrhyncha) from the Middle Jurassic Haifanggou Formation, western Liaoning, northeast China support stratigraphic correlation with the Daohugou beds. - Alcheringa 1: 53-61.

Klimaszewski S.M. \& Popov Y.A. 1993: New fossil hemipteran insects from southern England (Hemiptera: Psyliina + Coleorrhyncha). - Ann. Upper Siles. Mus. (Entomol.) Suppl. 1: 13-36.

Lin Q.B. 1986: Early Mesozoic Fossil Insects from South China. Science Press, Beijing, 112 pp. [in Chinese].
LinNAEUS C. 1758: Systema naturae per regna tria naturae, secundum classes, ordinus, genera, species, cum characteribus, differentiis, synonymis, locis. 10th ed., Vol. 1. Holmiae, Salvii, $824 \mathrm{pp}$.

Martins-Neto R.G., Gallego O.F. \& Melchor R.N. 2003: The Triassic insect fauna from South America (Argentina, Brazil and Chile): a checklist (except Blattoptera and Coleoptera) and descriptions of new taxa. - Acta Zool. Cracov. 46: 229-256.

MarTYNov A.V. 1926: Jurassic fossil insects from Turkestan. 6. Homoptera and Psocoptera. - Bull. Acad. Sci. USSR 20: 1349-1366 [in Russian].

Myers J.G. \& China W.E. 1929: The systematic position of the Peloridiidae as elucidated by a further study of the external anatomy of Hemiodoecus leai China. - Ann. Mag. Nat. Hist. 3: $282-294$.

Popov Y.A. 1982: Early Jurassic hemipterans of the genus $\mathrm{Ol}$ gamartynovia (Hemiptera, Progonocimicidae) from the Middle Asia. - Paleontol. Zh. 2: 80-95 [in Russian].

Popov Y.A. 1985: Jurassic bugs and Coleorrhyncha of southern Siberia and western Mongolia. - Tr. Paleontol. Inst. Akad. Nauk SSSR 211: 28-47 [in Russian].

Popov Y.A. 1986: Peloridiina (= Coleorrhyncha) et Cimicina (= Heteroptera). Insects in Early Cretaceous ecosystems of western Mongolia. - Tr. Joint Soviet-Mongol. Paleontol. Exped. 28: 47-84 [in Russian].

Popov Y.A. 1988: New Mesozoic Coleorrhyncha and Heteroptera from eastern Transbaikalia. - Paleontol. Zh. 4: 67-77 [in Russian].

Popov Y.A. 1989: New fossil Hemiptera (Heteroptera + Coleorrhyncha) from the Mesozoic of Mongolia. - N. Jb. Geol. Paläontol. Monath. 3: 166-181.

Popov Y.A. \& ShcherbaKov D.E. 1991: Mesozoic Peloridioidea and their ancestors (Insecta: Hemiptera, Coleorrhyncha). Geol. Palaeontol. 25: 215-235.

Popov Y.A. \& ShcherbaKov D.E. 1996: Origin and evolution of the Coleorrhyncha as shown by the fossil record. In Schaefer C.W. (ed.): Studies on Hemipteran Phylogeny. Thomas Say Publications in Entomology. Entomological Society of America, Lanham, MD, pp. 9-30.

Popov Y.A. \& Wootton R.J. 1977: The Upper Liassic Heteroptera of Mecklenburg and Saxony. - Syst. Entomol. 2: 333-351.

Popov Y.A., Dolling W.R. \& Whalley P.E.S. 1994: British Upper Triassic and Lower Jurassic Heteroptera and Coleorrhyncha (Insecta: Hemiptera). — Genus 5: 307-347.

Szwedo J. 2011: The Coleorrhyncha (Insecta: Hemiptera) of the European Jurassic, with a description of a new genus from the Toarcian of Luxembourg. — Volum. Jurass. 9: 3-20.

Szwedo J., AzAR D. \& ZiAdÉ K. 2011: The first Progonocimicidae (Insecta: Hemiptera: Coleorrhyncha) from Lower Cretaceous Lebanese amber. — Insect Syst. Evol. 42: 161-177.

Tillyard R.J. 1926: Kansas Permian insects. Part 6. Additions to the orders Protohymenoptera and Odonata. - Am. J. Sci. (Ser. 5) 11: 58-73.

Wang B., Szwedo J. \& Zhang H.C. 2009: Jurassic Progonocimicidae (Hemiptera) from China and phylogenetic analysis of Coleorrhyncha. - Sci. China (D, Earth Sci.) 52: 1953-1961.

Wang B., Szwedo J., Zhang H.C. \& Lin Q.B. 2011: The first Peloridioidea (Hemiptera) from China. - Acta Palaeontol. Sin. 50: 321-325.

WootTon R.J. 1963: Actinoscytinidae (Hemiptera: Heteroptera) from the Upper Triassic of Queensland. - Ann. Mag. Nat. Hist. 6: 249-255.

Received March 8, 2017; revised and accepted July 12, 2017 Published online August 14, 2017 